\title{
Det tabte Tjetjenien: Erindringer fra en borgerkrig
}

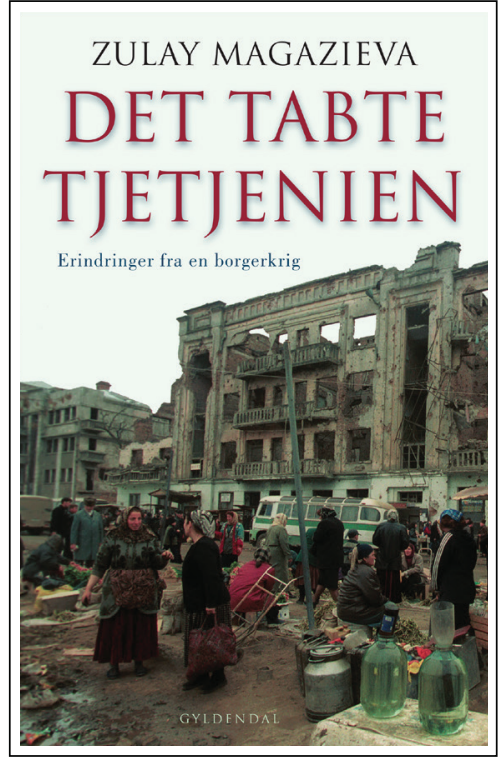

Zulay Magazieva

København: Gyldendal 2020

204 sider. ISBN: 9788702292800

Omtalt av Maryam Sugaipova [rådgiver ved Norsk Utenrikspolitisk Institutt, masu@nupi.no]

1994 var et bemerkelsesverdig år på flere måter. Folkemordet i Rwanda finner sted; MS «Estonia» synker i Østersjøen; Nelson Mandela innsettes som president i SørAfrika og apartheid er endelig over; forskjellige etniske grupper er i en bitter konflikt i Jugoslavia; langt øst i Europa beordrer den russiske presidenten Boris Jeltsin russiske tropper inn i Tsjetsjenia under påskuddet av å gjenopprette konstitusjonell orden. Det som skulle bli kjent som Tsjetsjenia-krigene er i dag for lengst glemt av det internasjonale samfunnet. Ettervirkninger fra krigene blir også aktivt fortrengt av overlevende, og historien blir systematisk omskrevet i dagens Russland. I dag, mange år etter begynnelsen av den første krigen i 1994 og den offisielle slutten av den andre krigen i 2009, er Tsjetsjenia et sted assosiert med vold, radikalisme, undertrykkelse av kvinner og minoritetsgrupper, utenomrettslige drap og forsvinninger. Hva har skjedd med den lille republikken sør i Russland, hvis historie og nåtid er preget av konflikter, og hvor folk i flere århundrer har slåss mot Russland for sin uavhengighet?

Boken Det tabte Tjetjenien av Zulay Magazieva er en personlig, rystende beretning om disse krigene, Tsjetsjenia og dets historie. Magazieva jobbet tidligere som 
journalist for tsjetsjenske nyhetsmedier og har også vært frivillig medarbeider i menneskerettsorganisasjonen Memorial i Groznyj. Hun har sett og opplevd mer enn et ungt menneske burde. Gjennom 1990-tallet og begynnelsen av 2000-tallet, med kamera i hånden, drar hun og kollegaer på kryss og tvers iTsjetsjenia for å dokumentere de utallige massegravene og bortføringene. Dette er, som hun selv sier, en måte å kjempe for rettferdighet for de drepte og bortførte. Hun har selv et veldig personlig forhold til krigen: to av brødrene hennes døde, den tredje ble bortført av russiske styrker og er også antatt død. Det er denne personlige tragedien og opplevelsen av krigens grusomheter i all sin brutalitet som har giort henne nummen og likegyldig til livet. Magazieva beskriver misunnelse overfor de døde for at de nettopp er døde og ikke lenger trenger å leve med ettervirkningene av krigen; "For dem er alt forbi» (s. 204). Gjennom detaljerte beskrivelser av bombardementer, krigshandlinger, bortførelser, tortur og de stadige zatsjistkaene (russiske "opprenskingsoperasjoner»), er det nettopp smerten til de overlevende som står i sentrum i historien hennes.

Disse førstehåndsberetningene er ulidelig vanskelige å lese: de treffer så hardt. Situasjonene Magazieva kommer opp i og historiene hun forteller er så til de grader absurde og uvirkelige, at det nesten er vanskelig å tro at de kan være sanne. Slik er krigens brutalitet. Som, for eksempel, den gangen hun kjører i en minibuss sammen med kollega Natasja (den tsjetsjenske menneskerettighetsaktivisten Natalia Estemirova, som ble drept i 2009) til landsbyen Geldogan over en bro. Der ser de en ung, halvnaken mann stå på knærne nede ved bredden og en gruppe russiske soldater som står med geværene sine rettet mot ham. Mens dette foregår kjører bussen rolig forbi, som om denne unge mannen ikke skal bli drept i neste sekund. For hva skulle de ha gjort? Alle ville blitt drept selv, dersom de grep inn. Hvor absurd er ikke en slik situasjon?

Det er flere ganger jeg må legge fra meg boken for å hente meg litt inn igjen. Men disse rystende historiene er svært viktige å skrive om, lese om og huske. Det er ikke lenger siden enn 2003 at hovedstaden i Tsjetsjenia, Groznyj, var blitt bombardert av den russiske hæren i så omfattende grad at FN erklærte byen for den mest ødelagte byen i hele verden. Men i dag er byen gjenoppbygget og skimrer som et Dubai i miniatyr. Det finnes ikke lenger fysiske spor av krigen i landet, og innbyggerne har blitt beordret til å glemme den - mennesker som ikke har fått mulighet og lov til å bearbeide sine post-traumatiske, psykiske lidelser går rundt som tikkende emosjonelle bomber. Det er også derfor Magazievas bok treffer så nært og gjør ordentlig vondt å lese, særlig for en tsjetsjener. Hun minner om hvor viktig det er å huske, gjenfortelle og la den delen av den tsjetsjenske historien leve videre.

Jeg setter stor pris på denne boken. Det finnes alt for lite god litteratur om Tsjetsjenia-krigene, spesielt som er utgitt på et annet språk enn russisk og skrevet av noen som har opplevd krigene på nært hold. Mange i det internasjonale samfunnet forbinder ofte 1990-tallets kriger i Tsjetsjenia med terrorister og gisseltaking, som i Dubrovka-teateret i 2002 eller på skolen i Beslan i 2004. Det var først og fremst disse hendelsene som nådde ut i media. Men Magazieva går dypere enn det og tegner et 


\section{2 | MARYAM SUGAIPOVA}

bilde av et lite og stolt folkeslag som prøvde å frigjøre seg fra russisk styre, på godt og vondt. Hun kontekstualiserer konflikten. Dette er viktig lesning for de som ønsker å forstå krigene bedre, og også for de som trenger å minnes dem. Historien skrives som regel av seierherrene, og tsjetsjenere har i dag liten mulighet til å bevare den sanne historien om krigene som herjet i landet deres. Historien har systematisk blitt skrevet om - i seierherrenes favør. Jeg takker Zulay Magazieva for at hun har klart å berette om disse utenkelige historiene, for hennes mot, kompromissløshet og integritet. 